\title{
Visual rehabilitation in pre phthisis bulbi's patient: case report
}

\author{
Reabilitação visual em paciente com pré phthisis bulbi: relato de caso
}

\author{
Priscila Ciocler Froiman ${ }^{1}$ \\ Carlos Eduardo Villas Bôas Júnior ${ }^{2}$ \\ Maria Auxiliadora Monteiro Frazão Sibinelli ${ }^{3}$ \\ Silvia Veitzman ${ }^{4}$ \\ Giceli Rodrigues Chaves Rinaldo ${ }^{5}$
}

\begin{tabular}{|l|}
\hline ABSTRACT \\
\hline Uveitis is a group of intraocular inflammatory diseases that affects mainly \\
patients of working age. Vogt-Koyanagi-Harada disease is a chronic, \\
granulomatous, systemic and autoimmune disease with manifestations \\
in the eye, skin, and hearing and nervous systems. Ocular complications \\
include cataract, glaucoma, choroidal neovascular membrane formation, \\
and subretinal fibrosis, which can lead to phthisis bulbi with profound \\
low vision or even blindness. The purpose of this article is to present the \\
visual rehabilitation of a young patient with pre phthisis bulbi as a com- \\
plication of the uveitis. During the active stage of the disease the patient \\
quit her studies in a crucial phase of her life. After clinical treatment and \\
surgery, training program of optical device adaptation and residual \\
visual optimization were performed. Due to the great patient's motivation, \\
it was possible to reintegrate her to social life.
\end{tabular}

Keywords: Uveitis/complications; Uveitis/surgery; Vision, low/rehabilitation; Human; Female; Adult; Case reports [Publication type]

\section{INTRODUCTION}

Uveitis is a term used to describe a group of intraocular inflammatory diseases that can occur at any age but predominantly affects patients of working age group $^{(1)}$. It can cause devastating visual loss and it is the fifth commonest cause of visual loss in the developed world, accounting for about $10-15 \%$ of the cases of total blindness (World Health Authority definition) and up to $20 \%$ of legal blindness ${ }^{(2)}$. The WHO defines blindness as the best corrected vision in the better eye of less than 3/60 or a visual field $10^{\circ}$, whereas severe visual impairment is defined as the best corrected visual acuity in the better eye of $3 / 60$ or more, but less than $6 / 60$ or a visual field $\leq 20^{\circ(3)}$. Bilateral visual loss impacts on the individual's ability to take on vision dependent tasks associated with daily living and on the emotional state. The adaptation to visual loss involves developing strategies to optimize the residual vision and adjusting to a new situation. This adaptive process, visual rehabilitation, may involve the acquisition of optical and non-optical aids and appliances, strategies and modifications of the visual environment including the use of new lighting and contrast enhancement techniques.

Our goal is to show the rehabilitation of a patient whose prognosis for recovery was poor before the surgery because her eyes were already on atrophy. Through the visual assessment the appropriate optical aid was determined. It allowed her to go back to school and do tasks like reading. The MNREAD ${ }^{\circledR}$ reading test was crucial to choose the best optical aid and to measure the progress of the training program. 


\section{CASE REPORT}

KSS, female, 20 years old, Brazilian from São Paulo, informed a progressive vision loss for 3 years, with bilateral ocular hyperemia and was diagnosed as uveitis complicated with bilateral cataract. She initiated treatment with oral prednisone, $30 \mathrm{mg}$ once daily, topical loteprednol $1 / 1 \mathrm{~h}$ and atropine $12 / 12 \mathrm{~h}$ in the right eye and topical dexametasone $8 / 8 \mathrm{~h}$ and atropine $12 / 12 \mathrm{~h}$ in the left eye. Then she was referred to Santa Casa de Misericórdia de São Paulo for evaluation and follow up. The first evaluation in this service was on May $31^{\text {st }}$, 2006. In her background, she reported contact with dogs and an aunt with diabetes mellitus. The general physical examination presented hyperpigmented scars on the skin. The BCVA in OD was 20/400 and in OS was light perception. The photomotor direct and consensual pupillary reflexes were absent in both eyes. Intraocular pressures were: OD $0 \mathrm{mmHg}$ and OS $2 \mathrm{mmHg}(09: 30 \mathrm{pm})$. Biomicroscopy in both eyes showed conjunctival hyperemia $+/ 4+$; the anterior chambers were deep with no cells and + flare; old KPs in lower half of the cornea in OS; $360^{\circ}$ posterior synechiae with pupillary membrane (occlusion) and cataract which was hard to visualize. The cataracts precluded fundus view. Laboratory investigations included negative serology for toxoplasmosis, toxocariasis, TST, VDRL, FTA abs, ELISA HIV 1 and 2, HLA B27 and FAN. Thorax XR was normal. The ocular A- and B-scan showed decreased axial length in both eyes (right $18.83 \mathrm{~mm}$ and left $18.95 \mathrm{~mm}$ ), thickening of choroid without calcification and posterior vitreous detachment. In spite of the poor prognosis, phacoemulsification with PC-IOL surgery and release of synechias were performed in OD on July $13^{\text {th }}, 2006$ and in OS on September $21^{\text {st }}$, 2006. After surgery, fundoscopy was done and revealed diffuse rarefaction of the RPE with Dallen-Fuchs nodules, migration of RPE and optic disc hyperemia, then being diagnosed as Vogt-Koyanagi-Harada disease.
Because of the success of the surgery she was referred to visual rehabilitation for the training program to improve her reading performance.

She was seen for the first time by the low vision team service in the Ophthalmology Department of Santa Casa Hospital on November $1^{\text {st }}, 2006$. Her main objectives were reading, managing computers and doing craft working. She wanted to learn Braille because she was not aware of her visual potential after surgery. She was unable to remain at school in an early stage of her illness and wanted to return to her studies and then to work. Evaluating her visual functions, we concluded that the adaptation of optical resources was compatible with her residual vision.

\section{Visual function evaluation}

- Visual acuity - (BCVA): OD 10/63 +8.00 sph $=-2.75$ cyl $15^{\circ}$ OS $10 / 63+4.00 \mathrm{sph}=-3.50 \mathrm{cyl} 170^{\circ}$

- Contrast sensitivity "Precision Vision Test": reduced

- Visual Field - Goldman Perimeter: Targets V, III, II and I-4 (Figure 1).

- Colour Vision Test (Large Stimulus) Farnsworth 16 Hue: normal

- Reading speed test (MNREAD Portuguese version).

- With no optical devices - Best reading acuity: 1.2 logMAR and best reading speed: $30 \mathrm{wpm}$.

- With telescope 6x - best reading acuity: 0.1 logMAR.

- With: +16 D OD - best reading speed: $270 \mathrm{wpm}$.

The best optical aid was chosen taking into account her goals and her visual function assessment. A monocular 6x telescope for reading and for distance (visual acuity 10/20) and +16.00 in OD for reading (visual acuity $0.6 \mathrm{M}$ ) for computer and craftwork were prescribed. Her performance improved after training.

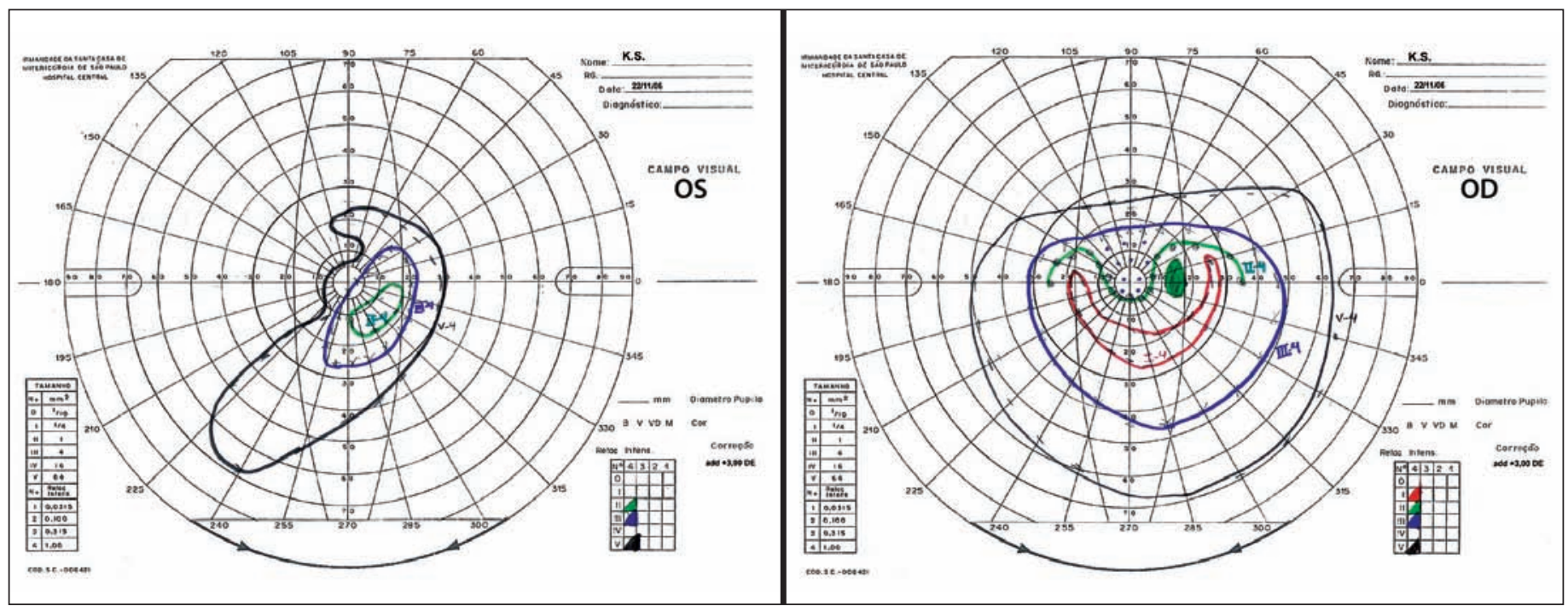

Figure 1 - Visual field: OD superior depression and OS generalized constriction 


\section{DISCUSSION}

Uveitis represents the main cause of vision loss in the 2060 years age group, and we must take into account that blindness caused by this disease is potentially treatable. With the majority of patients in the working age group, the financial and social costs are expressive ${ }^{(2)}$. Social factors, such as driving, social activities, and pastimes may also be affected ${ }^{(4)}$. Patient's quality of life is worse in younger patients with poor binocular visual acuity.

Vogt-Koyanagi-Harada complications include cataract, glaucoma, choroidal neovascular membrane formation, and sub retinal fibrosis, may limit the final visual acuity ${ }^{(5)}$. In this case, in spite of the poor prognosis due to the complications of such disease, the patient was very motivated and agreed with the surgery. So phacoemulsification with intraocular lens (IOL) implantation surgery and the release of synequias were performed. Because of the successful surgeries she was referred to visual rehabilitation for training reading performance and optimizing the use of residual vision. For many years, the ocular hypotony was considered a contra-indication for cataract surgery because of its poor prognosis. However, this situation showed us that in cases when the patient is young, hardworking and motivated, we can try to treat the patient because the results can be surprising.

The functional evaluation and classification of impaired vision are important for the patient, the family and involved professionals. The disease can suggest the functional characteristics and guide the rehabilitation. However, there are usually combined defects and their assessment are the key to determine the objectives for a better functional rehabilitation.

Through her visual function evaluation we concluded that the residual vision was compatible to low vision aids adaptation. The visual field justified the use of the optical aids in OD and the absence of difficulty to walk independently. As the contrast sensitivity was reduced, more magnification was required.

The motivation in patients with low vision in reading is crucial. The prescription of optical aids for reading should not be based only on visual acuity, but also in the fluency of text reading ${ }^{(6)}$. A standardized clinical reading test can give a valid prediction of the reading speed that a low-vision patient is likely to achieve with a magnifier. A normal vision reader can read between 200 and 300 words per minute ${ }^{(7)}$. Our patient could get this level after appropriate training, so both reading acuity and reading speed showed improvements which demonstrate that the main objective was achieved.

Therefore, the prior patient who was considered almost blind and had entered a Braille course is now capable of reading and is a regular productive person who is working, studying and is absolutely independent as she used to be.

\section{RESUMO}

Uveíte é o termo utilizado para descrever um grupo de doenças inflamatórias oculares que ocorrem predominantemente na idade produtiva. Vogt-Koyanagi-Harada é uma doença sistêmica, autoimune, granulomatosa, crônica com manifestações oculares, neurológicas, auditivas e cutâneas. As principais complicações incluem catarata, glaucoma, membrana neovascular e fibrose sub-retiniana, que podem evoluir para atrofia ocular, baixa visão profunda e cegueira. O propósito deste artigo é apresentar um caso de reabilitação visual em paciente jovem com pré phthisis bulbi consequente às complicações da uveíte. Após tratamento clínico e cirurgia, um programa de treinamento e adaptação de recursos ópticos foi realizado para otimizar o uso do resíduo visual, motivando a paciente para reintegrar-se socialmente e voltar aos estudos.

Descritores: Uveíte/complicações; Uveíte/cirurgia; Baixa visão/reabilitação; Humano; Feminino; Adulto; Relatos de casos [Tipo de publicação]

\section{REFERENCES}

1. Suttorp-Schulten MS, Rothova A. The possible impact of uveitis in blindness: a literature survey. Br J Ophthalmol. 1996;80(9):844-8.

2. Durrani OM, Tehrani NN, Marr JE, Moradi P, Stavrou P, Murray PI. Degree duration and causes of visual loss in uveitis. Br J Ophthalmol. 2004;88(9): 1159-62.

3. World Health Organization. Management of low vision in children [Internet]. Bangkok, 23-24 july 1992. [cited 1995 Feb 12]. (WHO/PBL/93.27) Available from: http://whqlibdoc.who.int/HQ/1993/WHO_PBL_93.27.pdf

4. Nussenblatt RB. The natural history of uveitis. Int Ophthalmol. 1990;14(5-6): 303-8.

5. Gardiner AM, Armstrong RA, Dunne MC, Murray PI. Correlation between visual function and visual ability in patients with uveitis. Br J Ophthalmol. 2002; 86(9):993-6.

6. Mansfield JS, Legge GE, Bane MC. Psychophysics of reading XV: Font effects in normal and low vision. Invest Ophtalmol Vis Sci. 1996;37(8):1492-501.

7. Ahn SJ, Legge GE. Psychophysics of reading-XIII. Predictors of magnifieraided reading speed in low vision. Vision Res. 1995;35(13):1931-8. 